\title{
EXTRATERRITORIAL APPLICATION OF EU COMPETITION LAW: THE NEW STANDARD- BEARER OF LEGAL IMPERIALISM?
}

\author{
Hüseyin Çağrı ÇORLU* \\ Research Article
}

\begin{abstract}
The effects doctrine has been a major instrument in dealing with foreign conduct having repercussions on the competitiveness of national markets. The aggressive implementation of the doctrine by US courts in competition law cases has caused clamor in international community. In EU law, on the other hand, the effects doctrine had long been ignored by the CJEU, which exercised its jurisdiction on the basis of territoriality principle. In Intel, the CJEU finally endorsed the effects doctrine. This paper questioned the CJEU's designation of the effects doctrine as a means to establish territorial jurisdiction over extraterritorial conduct. This paper concluded that the CJEU's approach to extraterritoriality would result in an overarching application of EU competition rules over foreign conduct.
\end{abstract}

Keywords: Extraterritoriality, Competition Law, Intel, Effects Doctrine, Component Cartels, Jurisdiction.

\section{AB Rekabet Hukuku'nun Sınır-Aşırı Uygulanması: Hukuk Emperyalizmi'nin Yeni Sancaktarı?}

$\ddot{O} z$

Etki doktrini, yerel rekabete etkileri olan sınır-aşırı eylemlerin tespiti ve kovuşturulması açısından önemli bir araç olarak karşımıza çıkmaktadır. Bu

\footnotetext{
* Assistant Professor at Necmettin Erbakan University, Law School, Konya, Turkey. E-mail: hccorlu@erbakan.edu.tr, ORCID: 0000-0002-8205-9596.

Makalenin Gönderilme Tarihi: 30/03/2021 Kabul Edilme Tarihi: 28/09/2021
} 
doktrinin ABD tarafindan katı bir şekilde uygulanması, diğer devletler tarafindan kendilerinin egemenlik haklarina yönelik bir ihlal olarak değerlendirilmiş ve bu sebeple uluslararası toplumun sert tepkisine yol açmıştır. AB hukukunda ise AB Adalet Divanı, uzun süre boyunca etki doktrinini görmezden gelmiş ve genellikle hukuki yetkisinin sinırların ülkesellik ilkesi üzerinden belirlemiştir. Divan Intel kararında etki doktrinini kabul etmiş fakat yine de bu çerçevede uyguladiğ yargl yetkisini ülkesellik ilkesi üzerinden kurmaya devam etmiştir. Bu çalışma, Divanın bu kararını sorgulamakta ve özellikle AB rekabet hukukunun üye devlet mahkemelerinde uygulanması aşamasındaki etkilerini incelemektedir. Çalı̧̧ma, Divanın kararının, AB hukukunun AB sınırları dışındaki eylemler için kapsamlı bir şekilde uygulanmasına neden olacă̆ını öngörmektedir.

Anahtar Kelimeler: Sinır-aşırılık, Rekabet Hukuku, Intel, Etki Doktrini, Birleşen Kartelleri, Yargı Yetkisi.

\section{Introduction}

First introduced in the United States case law, the extraterritorial application of domestic competition rules has been a subject of controversy among academics and professionals from legal and political profession. US courts' practice of applying the Sherman Act over foreign practices received a strong protest from their foreign counterparts conceiving such an exercise of jurisdiction as a violation of state sovereignty under public international law. Last two decades, however, saw a decline in this clamor due to certain decisions from US Supreme Court, which sought to alleviate these concerns and limit the scope of its extraterritorial jurisdiction through an effective implementation of international comity standards. In the European Union, on the other hand, courts adhered to traditional forms of jurisdiction and rejected extraterritoriality as a basis for their jurisdictional authority.

In 2017, the contention over the extraterritorial application of competition rules resurfaced due to the recent decision of the Court of Justice of the European Union (CJEU), Intel. In this case, the court finally gave away to the effects doctrine as a basis for judicial jurisdiction and fined a foreign company for practices committed abroad. Nevertheless the CJEU provided very little guidance on the legal implications of its newly adopted doctrine, sparking more questions than those had it unraveled. Ambiguities in construing these legal implications began to emerge, when national courts 
of EU Member States, following the CJEU's decision in Intel, sought to apply their competition rules to extraterritorial conducts.

Controversies as to the post-Intel application of EU competition law to extraterritorial conduct are two-fold; the extent of extraterritorial conduct that would be regarded within the scope of EU competition law under the newly adopted effects doctrine and, the status of international comity within the legal analysis carried out by EU courts. While the former identifies the types of market practices that are of foreign nature yet still to be subjected to EU law, the latter evaluates whether EU law should be applied to those practices. As a form of jurisdictional rule of reason, the latter question would not be asked without answering the former. Hence this paper follows the same logic, assessing first, the legal implications of Intel as to the extent of extraterritorial conduct to be considered within the scope of EU competition law and second, the approach taken by EU institutions and courts to the principle of international comity.

In so doing, the first section of this paper explores the development and evolution of the CJEU's position prior to Intel, with respect to the application of EU competition rules to foreign practices that created anticompetitive effects within the EU's internal market. This section demonstrates that CJEU refrained from endorsing the doctrine albeit the pressure from the European Commission (the Commission hereinafter) and academic literature. Instead the court devised other regulatory tools, such as the single economic unit and the implementation doctrines to cope with these types of market practices. This section identifies that functioning of these doctrines for establishing a territorial nexus between foreign practices and their effects in the internal market was limited. Given the advent of new supply chains in international trade, the CJEU found it necessary to endorse the effects doctrine in Intel. In the second section, the paper evaluates the legal implications of the CJEU's decision in Intel for the application of EU competition law to foreign conduct. Providing comparisons with the US jurisprudence on extraterritoriality, the paper presents a thorough analysis, demarcating the scope of EU competition law as recalibrated by the Court's findings in Intel. Finally the paper provides conclusions on this recalibration assessing whether it accounts for a new form of legal imperialism or not. 


\section{Evolution of the Extraterritorial Application of EU Competition Law}

\section{A. General}

A comprehensive set of rules that determines legal bases, on which the forms of jurisdictions ${ }^{1}$ would be exercised, has been absent in public international $\mathrm{law}^{2}$. Traditionally, two bases have been explicitly recognized; nationality and territoriality. While the principle of nationality focuses on the nationality of perpetrators, that of territoriality determines jurisdictions on the basis of where transactions or acts have been perpetrated. The jurisdiction of a State within its territory or over its nationals is exclusive and absolute, as a result of the sovereign rights enjoyed by that State under public international law. Nevertheless, this does not lead to a conclusion that apart from these bases, States can invoke no other grounds to assert their jurisdictions.

Public international law does not provide a specific prohibition enjoining States from exercising their jurisdictions on a basis other than nationality or territoriality ${ }^{3}$. This absence creates a field of conflict between multiple jurisdictions where multiple assertions of legal authorities were raised. Legal doctrine provides that the lack of a comprehensive set of rules

1 Public international law traditionally distinguished three forms of jurisdiction; legislative, executive, and judicial. Legislative jurisdiction determines whether legislature of a state has the authority to enact rules regarding to certain conduct. Executive jurisdiction, on the other hand, establishes the authority of a state to compel compliance with its law. Finally, judicial jurisdiction, identifies whether national courts or administrative tribunals are authorized to subject certain people or conduct to their judicial process. See: Lori F. Damrosch, et al., International Law: Cases and Materials, (5th ed., West 2009): 755. While in US case law legal arguments on the extraterritorial application of domestic competition rules has been generally made in relation with the judicial (subject-matter) jurisdiction, in EU case law they have mainly focused on legislative jurisdiction. The rationale underlying this distinction lays on the competences granted on the relevant administrative bodies with respect to the prosecution of anticompetitive practices. Whether judicial jurisdiction is the appropriate form for the evaluation of extraterritorial conduct in US law has been a subject of criticism by academics and judicial authorities. For further analysis, see: Josh A. Trenor, 'Jurisdiction and the Extraterritorial Application of Antitrust Law after Hartford Fire 'The University of Chicago Law Review 62, (1995): 1583.

2 Damrosch, (2009), 757.

3 In Lotus, the Permanent Court of International Justice (the PCIJ) identified that in the absence of a rule providing otherwise, States were allowed to assert their jurisdiction over persons or practices outside their territory. See: S.S. 'Lotus '(France v. Turkey), 1927 P.C.I.J. (ser. A) No. 10, para. 19. 
regulating jurisdictions in international relations should not be conceived as the existence of laissez faire for a state conduct ${ }^{4}$. States are obliged to determine the peripheries of their jurisdictions, taking into account those of others.

The concept of extraterritoriality fits in this field of conflict and relates to the exercise of national jurisdiction, when courts establish no connection with the nationality of perpetrators or the territoriality of a conduct contested. Disputes raised in relation with the extraterritoriality have been mostly concerned with the concurrent exercise of multiple jurisdictions over the same persons or conduct. The fact that a person or a conduct would be a subject of a jurisdiction without any national or territorial connection creates tensions between States ${ }^{5}$. These tensions have been particularly evident in competition law under which countries are committed to establish and preserve well-functioning national markets ${ }^{6}$. The question of how far a State should extend its jurisdiction to protect its national markets brings about discussions on the extraterritorial application of national competition rules.

\section{B. Advent of Extraterritorial Application of Competition Rules.}

It was the United States who, for the first time, sought to extend the reach of its competition rules over foreign practices on the basis of their anticompetitive effects on domestic markets. In Alcoa, Judge Hand ruled that US competition rules ${ }^{7}$ were applicable to foreign conduct, once it was established that inevitable effects on the US commerce were intended by culprits $^{8}$. Later identified as 'intended effects doctrine', Judge Hand's reasoning provided that 'any state may impose liabilities, even upon persons

4 Case Concerning Barcelona Traction, Light and Power Company Ltd. (Belgium v. Spain) ICJ. 1970, p. 105, See also; Roger P. Alford, Extraterritorial Application of Antitrust Laws: The United States and European Community Approaches Virginia Journal of International Law 33/1, (1992): 6

5 Eleanor M. Fox, 'National Law Global Markets and Hartford: Eyes Wide Shut' Antitrust Law Journal 68/1 (2000): 82.

6 The definition of a well-functioning national market has been subject to change across geography and time. See: Giuliano Amato, Antitrust and the Bounds of Power: the Dilemma of Liberal Democracy in the History of the Market (Oxford, Hart Publ. 1997).

7 Formally, competition rules enacted in the US are termed as antitrust rules as a reference to early practices engaged in by trusts during the late nineteenth century of the US. See: Ibid. For the purpose of coherence, the paper prefers to use the continental Europe's terminology of competition law, when referring US antitrust rules and the Sherman Act.

8 United States v. Aluminum Co of America, 148 F.2d 416424 (2d Cir. 1945). 
not within its allegiance, for conduct outside its borders that [had] consequences within its borders which the State reprehends...'9.

Reasoning of Alcoa was embraced and applied aggressively by other US courts ${ }^{10}$. This practice caused significant upheaval in the US's relations with other jurisdictions. Several countries, such as Canada, the United Kingdom, Australia, France, South Africa, Italy, the Netherlands, enacted blocking legislations which would forbid their national authorities from compliance with extraterritorial reach of US proceedings under competition rules ${ }^{11}$. The United Kingdom also enacted a 'claw-back' provision which allowed UK citizens and undertakings to reclaim two thirds of treble damages they were subjected for practices they committed outside the United States ${ }^{12}$.

In order to alleviate this external opposition, US courts introduced a jurisdictional rule of reason analysis and balancing tests that incorporated an assessment of several factors for the purposes of international comity ${ }^{13}$. Furthermore, in 1982, the Congress passed Foreign Trade Antitrust Improvements $\mathrm{Act}^{14}$ (FTAIA), which set out a taxonomy of market conduct for the extraterritorial scope of the Sherman Act, promulgating that in order for a foreign conduct to be governed by US competition rules, its effects on US commerce and trade should be direct, substantial and reasonably foreseeable, thereby introducing further limitations to jurisdictions of US courts. Even though the Supreme Court in Hartford Fire ${ }^{15}$ seemed to have renounced its adoption of balancing tests and comity analysis through its

$9 \quad$ Ibid., 443.

10 See: United States v. Imperial Chemicals Industries Ltd. 100 F. Supp. 504 (S.D.N.Y. 1951); United States v. Watchmakers of Switzerland Info. Center, Inc. 168 F. Supp. 904 (S.D.N.Y. 1958); Sabre Shipping Corp. v. American President Lines Ltd. 285 F. Supp. 949 (S.D.N.Y. 1968).

11 Roger P. Alford, ' Extraterritorial Application of Antitrust Laws: The United States and European Community Approaches' Virginia Journal of International Law 33/1, (1992): 10.

12 Donald E. Knebel, 'Extraterritorial Application of US Antitrust Laws: Principles and Responses' Jindal Global Law Review 8/2 (2017): 192.

13 Timberlane Lumber Co. $v$ Bank of America, 549 F2d 597 ( $9^{\text {th }}$ Cir 1976). In Mannington Mills, the 3rd Circuit identified ten factors to be considered in its balancing process. Mannington Mills, Inc. v. Congloeum Corp., 595 F.2d 1287, 1297 (3rd Cir. 1979).

1415 U.S. Code $\S 6$ a.

15 Hartford Fire Ins. Co. v. California, 509 U.S. 764 (1993). 
'true conflict' ${ }^{16}$ standard, it later reaffirmed its endorsement of jurisdictional rule of reason in Empagran ${ }^{17}$ in which the Court concluded that the principle of international comity would counsel against applying its jurisdictions to foreign conducts when foreign effects of such conducts were independent from the effects felt in the US ${ }^{18}$ and that any finding in contrast would be regarded as 'an act of legal imperialism through legislative fiat' ${ }^{19}$. Therefore, the taxonomy of foreign conduct under the FTAIA and international comity analysis constitute two major elements for the extraterritorial application of US competition law.

\section{Outset of Extraterritoriality in EU Competition Law}

Articles 101 and 102 of the Treaty on the Functioning of the European Union (TFEU) are the main provisions that regulate competition in the EU's single market. Article 101 (1) prohibits; '... all agreements between undertakings, decisions by associations of undertakings and concerted practices which may affect trade between Member States and which have as their object or effect the prevention, restriction or distortion of competition within the internal market ...'. Article 102, on the other hand, sets out that; '(a)ny abuse by one or more undertakings of a dominant position within the internal market or in a substantial part of it shall be prohibited as incompatible with the internal market in so far as it may affect trade between Member States'.

The Commission has been the major proponent of the extraterritoriality of EU competition rules, on the basis of effects doctrine ${ }^{20}$. In its decisions,

16 The court regarded that it would engage in comity analysis only if a true conflict existed between laws of foreign jurisdictions and that of the US. True conflict would arise, when the targeted company could not conform to the laws of both jurisdictions without violating one of them. Ibid., 799.

17 F. Hoffmann-La Roche Ltd. v Empagran, 542 U.S. 155 (2004).

18 Ibid., 166.

19 Ibid., 167.

20 The first time the Commission addressed the application of EU competition rules on the basis of effects doctrine was in its decision Grosfillex \& Fillistorf, 64/233/EEC [1964] OJ L 64/915. The Commission's initiative in exercising its authority extraterritorially is embedded in its self-imposed agenda of being a trailblazer for European integration. See: Chad Damro, 'Building an International Identity: The EU and Extraterritorial Competition Policy', 8/2 Journal of European Public Policy 208, 216 (2001); Yusuf Akbar, 'The Extraterritorial Dimension of US and EU Competition Law: A Threat to the Multilateral System?'. 53/1 Australian Journal of International Affairs 113, 119-20 (1999). 
the Commission persistently relied on effects of contested practices in asserting its jurisdiction ${ }^{21}$, alleging that the origins of anticompetitive effects on the internal market was irrelevant for the purposes of Articles 101 and 102 of $\mathrm{TFEU}^{22}$. Accordingly, the articles focused on behaviors that affected or were intended to affect the trade in the internal market or substantial part of it. Once the anticompetitive nature or intend of the conduct was established, foreign practices could also be contested under the EU Competition rules.

The Commission's inclination for adopting the effects doctrine was not shared by the CJEU. Until its decision in Intel, the Court refused to establish its jurisdiction on the basis of anticompetitive effects on the EU internal market. Instead, it referred to other principles such as 'the Single Economic Unit' and 'the Implementation' doctrines, which enabled the CJEU to demonstrate a physical nexus between foreign undertakings and conducts taking place within the EU internal market. Establishing legislative jurisdiction on the basis of territoriality was a universally recognized principle under public international law and this approach allowed the court to assess contested practices, under the territoriality principle without engaging in deliberations on the extraterritorial scope of EU competition rules $^{23}$. In so doing, the CJEU was confident that establishing the Commission's jurisdiction over these conducts would not account for an encroachment of sovereignty of other states and thus not result in a violation of public international law. Nevertheless, neither the single economic unit doctrine, nor the implementation doctrine was sufficient to cover the extent of anticompetitive practices, on which the Commission sought to assert its jurisdiction under EU competition rules.

21 See: In re the Cartel in Aniline Dyes [1969] OJ L195/11; Woodpulp [1985] OJ L85/1; Gencor/Lonrho (Case No IV/M.619) Commission Decision of 24 April 1996 OJ L11/30 [1997].

22 The competition rules of the Treaty are, consequently applicable to all restrictions of competition which produce within the Common Markets effects set in Article [101(1)]. There is therefore no need to examine whether the undertakings which are the cause of these restrictions of competition have their seat within or outside the Community. 'Re the Cartel in Aniline Dyes [1969] OJ L195/11, as cited in Alison Jones \& Brenda Sufrin, EU Competition Law: Text, Cases, and Materials (Oxford, 7th ed. 2019), 1197.

23 (T)he Community's jurisdiction to apply its competition rules to such conduct is covered by the territoriality principle as universally recognized in public international law. Case 89/85, A. Ahlström Osakeyhtiö and others v Commission [1988] ECR I-5193, 5243. 


\section{Single Economic Unit Doctrine}

The single economic unit doctrine was first introduced in the Dyestuffs ${ }^{24}$, which concerned price fixing practices of an alleged cartel established by the producers of aniline dyes incorporated outside the EU and having subsidiaries in the EU internal market. According to the Commission, there was no need to examine whether the companies were located inside or outside the Community, since Article 101 was directly applicable to all restrictions irrespective of their country of origin ${ }^{25}$. In appeal, Advocate General Mayras supported the Commission's application of effects doctrine and further stated that the CJEU should apply an 'effects test' examining whether foreign conduct had a direct, substantial and reasonably foreseeable restriction of competition in the Community ${ }^{26}$.

Noting that it had doubts as to the compatibility of the effects test with public international law ${ }^{27}$, the Court upheld the Commission's jurisdiction on the basis of the single economic unit doctrine, providing that ' $(t)$ he fact that a subsidiary [had] separate legal personality [was] not sufficient to exclude possibility of imputing its conduct to the parent company' ${ }^{28}$. The Court continued ' $(w)$ here a subsidiary [did] not enjoy real autonomy in determining its course of action in the market, the prohibitions set out in Article [101](1) may be considered inapplicable in the relationship between it and the parent company, with which it [formed] one economic unit' ${ }^{29}$.

Even though the single economic unit doctrine was extensively referred by the CJEU and the General Court in their decisions ${ }^{30}$, it provided only a

${ }^{24}$ Case 48/69, ICI v. Commission (Dyestuffs) [1972] ECR 619.

25 Case 48/69, ICI v. Commission (Dyestuffs) [1972] ECR 619, 624.

26 Opinion of Mr Advocate-General Mayras in Case 48/69, ICI v Commission (Dyestuffs) EU:C:1972:32, 695

27 Case 48/69, ICI v. Commission (Dyestuffs) [1972] ECR 619, 627. In international law, it would be wrong to accept the proposition that there exists a rule extending jurisdiction on the basis of effects doctrine, unless such a rule were universally acknowledged, which is not the case. Ibid., 631 .

28 Ibid., para. 132.

29 Ibid., para. 134.

30 See for example: Case 170/83, Hydrotherm Gerätebau GmbH v Compact del Dott. Ing. Mario Andreoli \& C. Sas. [1985] ECR 3016, para 11; Case T-11/89, Shell International Chemical Company Ltd [1992] ECR II-884, para. 311; Case 73/95 P, Viho Europe BV v Commission EU:C:1996:405; Case T-325/01 Daimler Chrysler Ag v Commission [2005] ECR II-3326, para. 218; Case 97/08 Akzo Nobel NV v Commission [2009] ECR I-8237, 
limited margin for EU courts to establish the jurisdiction over foreign anticompetitive conduct. The doctrine was silent on how competition rules would be applied to practices of foreign undertakings, which despite having no domestic subsidiaries, still affected competition within the internal market. The limitations of the doctrine revealed in $\operatorname{Wood} P u l p^{31}$, in which the CJEU found it necessary to contemplate a new approach to reach out these practices, without trespassing the peripheries of the territoriality principle.

\section{Implementation Doctrine}

Wood Pulp concerned a cartel consisting of non-EU producers of bleached sulphate wood pulp, a substance, used for the production of highquality papers. The Commission imposed fines on these undertakings, on the ground that they violated Article 101(1) of the TFEU by engaging in concerted practices to fix the prices of wood pulp products sold in the $\mathrm{EU}^{32}$. The undertakings challenged the Commission's decision before the CJEU, and alleged that lacking jurisdiction to apply the EU competition rules to the contested practices, the Commission was in violation of public international $\mathrm{law}^{33}$. Cartel members were not domicile in the EU and some of them did not have any domestic subsidiaries. Contested price fixing agreements were concluded outside the EU. The Commission asserted that Article 101 was applicable to the contested practices since they were intended to affect the internal market ${ }^{34}$.

As in Dyestuffs, the Advocate General opinion in Wood Pulp, counseled the CJEU to adopt effects doctrine ${ }^{35}$. AG Darmon contended that the reading of Article 101(1) suggested the location, in which anticompetitive effects materialized, as a determinative criterion for the application of EU competition law ${ }^{36}$. The Opinion promulgated that not all effects would result

para. 49; Cases 293-294/13 P, Fresh Del Monte Produce Inc. v. Commission [2015] ECLI:EU:C:2015:416, paras 76-100.

31 Case 89/85, A. Ahlström Osakeyhtiö and others v Commission [1988] ECR I-5193.

32 Wood Pulp (Case IV/29725) Commission Decision 85/202/EEC [1985] OJ L85/1.

33 Case 89/85, A. Ahlström Osakeyhtiö and others v Commission [1988] ECR I-5193, 5241.

34 Ibid., 5240.

35 Opinion of Mr Advocate General Darmon in Case 89/85, A. Ahlström Osakeyhtiö and others $v$ Commission [1988] ECR I-5193, para. 58.

36 'In the light of [Article 101(1)], the vast majority of academic writers take the view that it is neither the nationality not the geographical location of the undertaking, but the location 
in an exercise of legislative jurisdiction under EU competition rules. Referring to AG Mayras's formulation of 'qualified' effects test, AG Darmon suggested that only direct, substantial and reasonable foreseeable effects would be considered as a legal basis for the Court's jurisdictional analysis $^{37}$.

The CJEU, in its ruling, did not provide any conclusion as to the Commission's and AG Darmon's arguments on the effects doctrine. Nor did it rely on its earlier reasoning in Dyestuffs. The Court pointed out that an infringement of Article 101 involved two elements: where an agreement which corresponded to a concerted practice was formed, and; where this agreement was implemented ${ }^{38}$. If the place, in which an agreement was formed, was considered to be the only criterion for the application of EU competition rules, this would allow the perpetrators to restrict competition in the internal market with impunity. Therefore, the Court continued, the decisive criterion should be determined to be the place, in which this agreement was implemented ${ }^{39}$. The CJEU found that price fixing agreements for wood pulp products were implemented in the internal market, as they were directly sold to undertakings in the EU. Whether these undertakings were subsidiaries, or agents of the perpetrators were irrelevant for the determination of the jurisdiction. As long as these final products were directly supplied by the perpetrators, through direct sales to domestic undertakings, Article 101(1) would apply.

The reasoning of the CJEU in Wood Pulp, which would be referred as 'the implementation doctrine' in subsequent case law, recalibrated the scope of the single economic unit doctrine. As discussed, the latter was silent when sales into the EU was not made through a domestic subsidiary. In the case of former, on the other hand, the existence of a sale into the internal market was sufficient for the court to establish its jurisdiction. Furthermore, as in Dyestuffs, the Court considered the Commission's jurisdiction within the

of the anti-competitive effect which constitutes the criterion for the application of Community competition law'. Opinion of Mr Advocate General Darmon in Case 89/85, A. Ahlström Osakeyhtiö and others v Commission [1988] ECR I-5193, para. 9.

37 'In my view, not all of those characteristics have to be adopted if the effect is taken as the criterion of extraterritorial jurisdiction. The most important reservation in the regards concerns indirect effect. 'Ibid., para. 53.

38 Case 89/85, A. Ahlström Osakeyhtiö and others v Commission [1988] ECR I-5193, para. 16.

${ }^{39} \mathrm{Ibid}$. 
peripheries of the territoriality principle ${ }^{40}$. The conduct under scrutiny might be of an extraterritorial origin, yet was territorial as its implementation took place within the boundaries of EU Member States.

The CJEU's formulation of the implementation doctrine has been effective in regulating cartelized products once they are imported into the EU, even though they were produced and cartelized abroad. Nevertheless, this effectiveness was ensured only if that it is the final products that were cartelized and that these cartelized must be sold into buyers in the EU. This formulation also indicated that many practices, such as export boycotts, output restrictions by foreign manufacturers etc., would not be addressed by the implementation doctrine, since they did not involve a sale and importation into the EU internal market. Furthermore, this formulation did not foresee the application of EU Competition Law to component cartels in which products that were cartelized were components of final products which were produced and sold into the EU by manufacturers other those that were committed cartel agreements.

\section{The Path Towards Intel}

It was Innolux ${ }^{41}$ that represented the final stance of the CJEU against the endorsement of the effects doctrine within the meanings of Articles 101 and 102 of the TFEU ${ }^{42}$. The case concerned an extraterritorial concerted practice by six producers of LCD panels from South Korea and Taiwan. The producers were held liable of a violation of Article 101(1), on the ground that they engaged in a worldwide cartel agreement, fixing prices of LCD

40 Ibid., para. 14

41 T-91/11, InnoLux v Commission, [2014] ECLI:EU:T:2014:92; Case 231/14, InnoLux v Commission [2015] ECLI:EU:C:2015:451.

42 Prior to Intel and InnoLux, the General Court, had already confirmed the applicability of the effects doctrine, in its decision of Gencor. 'Application of the Regulation is justified under public international law when it is foreseeable that a proposed concentration will have an immediate and substantial effect in the Community' Case T-102/96, Gencor Ltd $v$. Commission [1999] ECR II-753, para. 90. Nevertheless, this case concerned a concentration arising from a merger agreement between multiple undertakings under the EU's Merger Regulation, on the basis of the concentration's prospective effects on the competitive structure of relevant EU markets. The GC's jurisdiction over the contested concentration was not asserted against a foreign conduct in violation of Articles 101 and 102 of TFEU. Council Regulation on the concentrations between undertakings 4064/89 [1989] OJ L395/1 (replaced by Reg. 139/2004 [2004] L24/1). For the Merger Regulation see: Council Regulation on the concentrations between undertakings 4064/89 [1989] OJ L395/1 (replaced by Reg. 139/2004 [2004] L24/1). 
panels globally ${ }^{43}$. The Commission distinguished three grounds that could be evaluated for calculating the fines to be imposed upon cartel members:

- Direct sales of panels to independent third parties in the European Economic Area (EEA);

- Direct sales of panels, incorporated outside the EEA into finished products by a vertically integrated company which the producer of panels are part of, to independent third parties in the EEA;

- Indirect sales of panels, incorporated outside the EEA into finished products by an undertaking not part of the vertically integrated company the producer of panels are part of, to independent third parties within the EEA ${ }^{44}$.

The Commission took into account only first two categories in its calculation of fines, considering that the inclusion of the third category into its calculation was not necessary for achieving a sufficient level of deterrence ${ }^{45}$.

InnoLux, one of the undertakings taking part in the cartel agreement, appealed to the GC alleging that the Commission's inclusion of the second category into the calculation of fines was not justified under 2006 Guidelines on method of setting fines ${ }^{46}$. InnoLux was a vertically-integrated company. LCD panels, produced by InnoLux, were bought by its wholly-owned subsidiaries outside the EU, which incorporated these panels into final products, such as televisions and computer screens, which were then sold to independent purchasers in the EU. Though concluded outside the EU, the Commission considered those cartel agreements as implemented in the EU, on the ground that the cartelized LCD panels affected the prices of final products that were sold into the EU, and thus distorted competition within the internal market ${ }^{47}$. InnoLux contested the Commission's methodology, since the subjects of the cartel agreements were the prices of LCD panels, rather than those of final products. Article 13 of the 2006 Guidelines

43 LCD — Liquid Crystal Displays (Case COMP/39.309) [2010] OJ 2011 C 295/8.

44 Ibid., para. 380

45 Ibid., para. 381

46 Guidelines on the method of setting fines imposed pursuant to Article 23(2)(a) of Regulation No 1/2003, 2006/C 210/02.

47 LCD - Liquid Crystal Displays (Case COMP/39.309) [2010] OJ 2011 C 295/8, para., 435. 
empowered the Commission to calculate fines as to the 'sales to which the infringement relates' and the Commission itself acknowledged that no infringement relating to the sales of final products had been found ${ }^{48}$. The infringement was perpetrated in relation with the sales of LCS panels. Thus the Commission's assessment should be limited to the direct sales of LCD panels to buyers in the EU.

The GC dismissed InnoLux's appeal, pointing out that sales of LCD panels to the producers of final products were part of 'a single and continuous infringement' of Article 101(1) ${ }^{49}$. The Commission's inclusion of these sales into its calculation was justified, since the cartelized LCD panels made their way towards the EU, through these final products under a vertically integrated company ${ }^{50}$, and the Commission's calculation did not take into account the full value of the sales of final products, but only a portion, corresponding to the value of LCD panels incorporated in the final products $^{51}$. In other words, the GC ignored the transactions, the producer of final products had contracted with both foreign producers of LCD panels, and domestic buyers of the final products. This omission provided a direct connection between the sales of LCD panels, and their arrival to the internal market through sales of final products. In so doing, the GC assumed a fictitious sale transaction between the EU buyers and LCD producers, which would concurrently materialize, once the former contracted with the producers of final products. When the final products were delivered into the $\mathrm{EU}$, the LCD panels incorporated in these product were also considered to be sold into the EU as separate products.

In Innolux, the GC sought to combine the single economic unit and implementation doctrines to assert its jurisdiction over foreign sales of LCD panels. None of the price fixing and cartel agreements were concluded in the $\mathrm{EU}$, and the products that were contracted to be delivered into the EU were not LCD panels. The EU buyers did not enter into transactions with their

48 T-91/11, InnoLux v Commission, [2014] ECLI:EU:T:2014:92, para. 35.

49 Ibid., para., 123. The GC identified single and continuous infringement as practices that is intended to deal with one or more consequences of the normal pattern of competition, and, through that interaction, contribute to the attainment of the set of anti-competitive effects desired by those responsible, within the framework of an overall plan having a single objective'. Ibid., para. 103.

50 Ibid., para. 71 .

51 Ibid., para. 45. 
counterparts to buy LCD panels. Instead, the subject of their transactions was the delivery of televisions and computers into the EU. The GC could not establish the jurisdiction over the LCD panels, based solely on the implementation doctrine, since the contracts implemented in the EU were regarding to the sales of final products, which were not cartelized. Agreements, regarding to the sales of cartelized LCD panels were implemented outside the EU. The single economic unit doctrine enabled the GC to combine two separate transactions into one. According to the GC, there was no 'real' agreement between two parties when the cartelized LCD products were sold to the producers of final products, since this sale was of a intra-firm character ${ }^{52}$. When these final products were sold into the EEA, they would be considered as partly cartelized products, based on the portion that LCD panels represented in their overall value. This perception allowed the GC to establish the Commission's jurisdiction on the basis of the implementation doctrine and within the premises of the territoriality principle $^{53}$.

The GC's conclusions were strongly criticized in AG Wathelet's opinion, which argued that the GC erred, in its interpretation of the implementation doctrine. The opinion stressed that the doctrine would provide a scope for territorial application of EU competition rules, only if it concerned 'direct sales of the relevant products to purchasers established in the Community' (emphasis omitted) ${ }^{54}$. Confirming that Single Economic Unit doctrine was a well-established concept in the EU case law. AG Wathelet argued that this doctrine would not necessarily result in a conclusion that the agreements, concluded between the parties belonging to the same company, were not 'real', and thus should not be taken into account ${ }^{55}$. The agreements, regarding to the sales of LCD panels between InnoLux, and its subsidiaries were implemented outside the EU, and thus could not be regarded within the territorial scope of EU competition law under implementation doctrine.

52 Opinion of Mr. Advocate General Wathelet in Case 231/14, InnoLux v Commission [2015] ECLI:EU:C:2015:292, para. 13.

53 T-91/11, InnoLux v Commission, [2014] ECLI:EU:T:2014:92, para. 60.

54 Opinion of Mr. Advocate General Wathelet in Case 231/14, InnoLux v Commission [2015] ECLI:EU:C:2015:292, para. 36.

55 Ibid., paras 32-33. 
The Opinion also suggested that the Commission's evidence, presented with respect to the effects, the cartelized LCD panels caused on the internal market, would not suffice to assert its jurisdiction on the basis of the 'qualified' effects doctrine. AG Wathelet provided that price fixing practices related directly to LCD panels, rather than the final products ${ }^{56}$. Since InnoLux engaged in no cartel agreements as to the sale of final products to purchasers in the EU, anticompetitive effects LCD panels had on the internal market could not be considered as direct. Furthermore, AG Wathelet argued that the Commission demonstrated no evidence on the effects incurred by these final products, due to their incorporation of cartelized LCD panels ${ }^{57}$. The GC's contention that cartelized LCD panels affected the prices of final products, rested on mere assumption by the Commission without any demonstration of how such effects had materialized.

AG Wathelet supported its position with a reference to a US case which closely resembled the one he was asked to counsel. In Motorola Mobility $L L C$ v. AU Optronics Corp., the Seventh Circuit refused to grant remedies based on pass-on claims where the claimants were not the direct buyers of cartelized products. AG Wathelet proposed that a similar ruling should be adopted by the CJEU as the effects of cartelized products on domestic buyers were indirect and thus would not satisfy the qualified effects doctrine.

Upholding the GC's decision, and rejecting InnoLux's appeal in its entirety ${ }^{58}$, the CJEU put emphasis on the vertical integration between InnoLux and its subsidiaries. The Court noted that 'vertically-integrated [might] benefit from a horizontal price-fixing agreement, concluded in breach of Article 101 the TFEU, not only sales [were] made to independent third parties on the market for the goods, the subject of the infringement, but also on the downstream market in processed foods made up of, inter alia, the goods which [were] the subject of the infringement $(\ldots)^{59}$. The CJEU argued that the objective of Article 13 of 2006 Guidelines was the setting of fines reflecting 'the economic significance of the infringement and the relative size of the undertaking's contribution to it ${ }^{60}$. Any decision held

56 Opinion of Mr. Advocate General Wathelet in Case 231/14, InnoLux v Commission [2015] ECLI:EU:C:2015:292, para. 56.

57 Ibid., para. 54.

${ }^{58}$ Case 231/14, InnoLux v Commission [2015] ECLI:EU:C:2015:451, para. 86.

${ }^{59}$ Ibid., para. 56.

${ }^{60}$ Ibid., para. 50. 
otherwise would result in a calculation of a fine, which did not reflect the significance of infringements committed by such vertically integrated undertakings ${ }^{61}$.

Neither the GC nor the CJEU referred to the effects doctrine in their evaluation of whether the Commission exercised its jurisdiction in pursuant to Article 101 the TFEU. Both courts established the Commission's jurisdiction on the basis of the implementation doctrine with a strong emphasis placed upon the appellant's vertical integration. Nevertheless, the demonstration of a nexus between the cartelized LCD panels, and their effects on EU markets through transformed final products were fundamental for establishing the jurisdiction. The applicability of the implementation doctrine depended upon the finding of anticompetitive effects the cartelized LCD panels inflicted upon the final products. The CJEU argued that these effects would materialize 'either the price increases of the inputs, which [resulted] from the infringement [were] passed on by those undertakings in the price of processed goods, or those undertakings [did] not pass these increases on, which thus effectively [granted] them a cost advantage in relation to their competitors, which [obtained] those same inputs on the markets $(\ldots)^{162}$.

The findings of the courts raised questions as to how they would establish their jurisdictions, in dealing with component cartels, when no vertical integration between producers of components and final products incorporating them existed. Both the GC and the CJEU relied on the vertical integration of the appellant in determining single economic unit. The reasonings of the Courts indicated that such a jurisdiction would not be established against foreign practices, unless a vertical integration existed ${ }^{63}$. The GC and the CJEU established the Commission's jurisdiction in Intel ${ }^{64}$, even though a vertical integration within the meaning of InnoLux was missing. This absence was fundamental in paving the way for the CJEU's endorsement of the 'effects doctrine'. Nevertheless, the CJEU's reasoning on this endorsement was very limited ${ }^{65}$ and thus sparked questions more than those it had unraveled.

${ }^{61}$ Ibid., para. 55.

62 Ibid., para. 56

63 Case T-91/11 InnoLux Corp. v. Commission, para. 90.

64 T-286/09, Intel v Commisson, ECLI:EU:T:2014:547, Case C-413/14 P Intel Corporation v Commission [2016] ECLI:EU:C:2017:632.

65 Eleanor M. Fox, 'Extraterritorial Jurisdiction, Antitrust and the EU Intel Case: Implementation, Qualified Effects, and the Third Kind', Fordham International Law Journal 42/3, (2019): 985. 


\section{E. Intel}

In 2009, Intel, a US-based manufacturer of, inter alia, central processing units (CPUs) which accounted for 70-80 per cent of global CPUs production ${ }^{66}$ was found in violation of Article 102 TFEU by the Commission on the ground that it had abused its dominant position in global CPUs market in detriment of $\mathrm{x} 86 \mathrm{CPUs}$ produced by its only appreciable competitor, Advanced Micro Devices (AMD). The alleged abuse took the forms of exclusive rebates that were granted to original equipment manufacturers (OEMs) such as Dell, Hewlett-Packard Company (HP), Acer Inc., Lenovo, etc. on the condition that these companies procured all or almost all of their CPU demand from Intel and naked constraints which connoted a direct payment by Intel to certain OEMs provided that they postponed or cancelled their products incorporating x $86 \mathrm{CPUs}$ produced by AMD. Accordingly, Intel was imposed 1.06 billion EUR fine, the largest amount ever imposed on an undertaking by then ${ }^{67}$.

Intel appealed to the GC, opposing, inter alia, the Commission's jurisdiction over its trading practices with Lenovo. Intel was a US producer of x 86 CPUs, while Lenovo was a Chinese producer of computers and other electronic devices. Agreements on exclusive rebates and naked restrictions between these companies were concluded through online correspondence in their respective countries, and their implementation was carried out by manufacturing facilities in China, in which Lenovo incorporated x86 CPUs, received from Intel, into its notebooks, and desktop computers. These two companies were completely independent without any integration at management or shareholding level. Since Intel's abuse in CPUs markets was implemented outside the EU, Intel argued that the Commission lacked necessary jurisdiction for applying EU competition law to its conduct ${ }^{68}$.

The GC confirmed the Commission's jurisdiction on the basis of both the implementation and qualified effects doctrines, addressing the latter as

66 Intel (Case COMP/37.990) [2010] OJ C227/13, para. 901.

67 Antitrust: Commission imposes fine of $€ 1.06$ bn on Intel for abuse of dominant position; orders Intel to cease illegal practices, https://ec.europa.eu/ commission/ presscorner/detail/en/IP_09_745. Intel (Case COMP/37.990) [2010] OJ C227/13, para. 1789.

68 T-286/09, Intel v Commisson, ECLI:EU:T:2014:547, para. 221. 
an alternative to the former ${ }^{69}$. The Court held that the Commission could exercise its jurisdiction on the basis of the implementation doctrine, since no computers incorporating AMD's CPUs would be available anywhere in the world, including the EU. This reasoning contradicted its findings in InnoLux, in which it relied on vertical integration between companies in establishing the jurisdiction of EU competition law, on the basis of the implementation doctrine.

This was addressed in AG Wahl's opinion who, though rejected AG Wathelet's proposition that only direct sales would suffice the application of implementation doctrine ${ }^{70}$, noted that a strong connection, such as the existence of a single economic unit or other corporate or structural links, should be established to determine whether the sale of a product incorporated abroad was implemented in the $\mathrm{EU}^{71}$. The court evaluated the implementation of the conduct on the basis of where its effects were felt, rather than where abusive practices themselves were perpetrated, without providing further details on how the nexus was established between territories of EU Member States and abusive practices perpetrated in China.

It is fundamental to note that contested practices in Intel were evaluated under Article 102 TFEU, which specifically prohibited abuse of dominance 'within the internal market'. Reading of the article suggested that practices that were regarded as abuses of dominance had to be perpetrated within the EU. Whether the relevant markets were established to be worldwide was irrelevant for the legal analysis under Article 102 TFEU. Nevertheless, the $\mathrm{GC}$ construed the article in a different manner ${ }^{72}$. According to the court, the factor that determined whether Article 102 should be applied to a conduct, was the place in which the dominance was established rather than where the abuse was perpetrated. The determination of a worldwide dominance would automatically result in a finding of a EU-wide dominance. Consequently, any abuse perpetrated anywhere in the world would be considered as an abuse of dominance, implemented within the internal market.

69 Ibid., para. 233. '(D)emonstrating the implementation of the practices at issue in the EEA or demonstrating qualified effects are alternative and not cumulative approaches for the purposes of establishing that the Commission's jurisdiction is justified under the rules of public international law'. Ibid., para. 236.

70 Opinion of Mr. Advocate General Wahl in Case C-413/14 Intel v Commission [2016] ECLI:EU:C:2016:788, para. 292.

71 Ibid.

72 Ibid., para. 247. 
Aware of the fact that there was not too much warrant within the text of Article 102 for its construing the implementation doctrine in this manner, the GC focused on the qualified effects doctrine, evaluating whether Intel's practices with respect to Lenovo agreements had foreseeable, immediate and substantial effects in the $\mathrm{EU}^{73}$. The $\mathrm{GC}$ found that, though not producing actual effects, the conduct of Intel was capable of producing restrictive effects in the $\mathrm{EU}^{74}$. The absence of actual effects would not prevent the Commission from finding an abuse of dominance under 102 TFEU. Once the contested conduct was regarded as capable of producing effects, the Court found it sufficient for a finding of a foreseeable effects in the EU. Since no computers incorporating AMD's CPUs would be available in the world including the EU, the effects of Lenovo agreements were considered to be immediate ${ }^{75}$. As to the element of substantiality, the Court considered exclusive rebates and naked restrictions together, on the ground that these practices formed a single and continuous infringement and concluded that prospective effects of these practices would be substantial ${ }^{76}$.

The GC's decision was strongly criticized in AG Wahl's opinion, prior to its appeal to the CJEU. Praising the GC's adoption of the qualified effects doctrine, AG Wahl argued that the Court's findings of anticompetitive effects in accordance with its interpretation of the doctrine appeared 'hypothetical, speculative and unsubstantiated' ${ }^{77}$. According to the opinion, the GC could not establish that rebates offered by Intel to Lenovo were exclusive, since the agreements referred by the Court did not indicate any obligation on Lenovo to buy all or almost all of its CPUs from Intel ${ }^{78}$. The market coverage of rebates offered was not at levels that would be considered as capable of producing anticompetitive effects on the internal market $^{79}$. AG Wahl noted that the mere possibility of these effects should not be regarded as sufficient for a determination of foreseeable effects in the EU, under the qualified effects doctrine ${ }^{80}$.

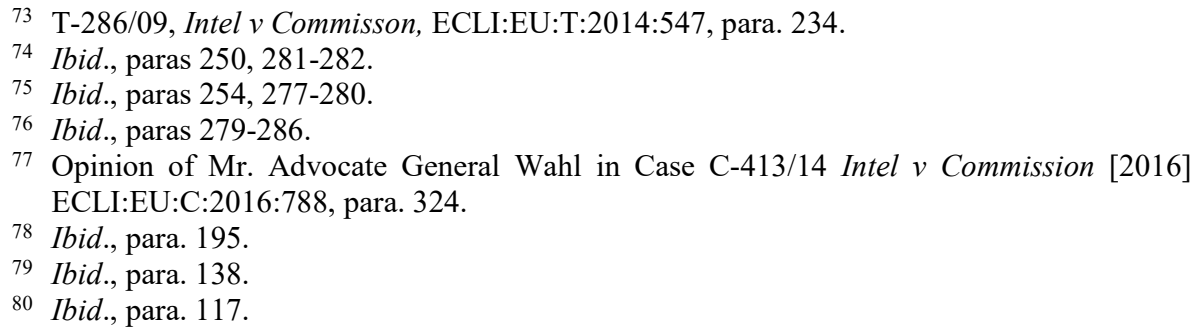


In the appeal the CJEU acknowledged the doctrine, for the first time, as a means for the Commission to assert its jurisdiction under EU competition law $^{81}$ and upheld the GC's conclusions thereof ${ }^{82}$, without providing any discussions on the criticism put forward by AG Wahl. Even though, reversing the GC's decision on the ground that the Commission failed in taking into account all circumstances that were of importance in determining whether the contested practices were capable of producing anticompetitive foreclosure in the internal market, the CJEU considered this ground of appeal under the merits of Article 102 TFEU, rather than its jurisdictional analysis under the qualified effects doctrine, contrary to the AG Wahl assessment. The CJEU promulgated that it was sufficient to satisfy foreseeability element of the qualified effects doctrine, once the contested practices were established to have probable effects on competition within the internal market ${ }^{83}$. As to the other elements of the doctrine, the CJEU just reiterated the findings of the $\mathrm{GC}$ and dismissed the objections, raised by the appellant ${ }^{84}$.

\section{Legal Implications of the CJEU's Decision in Intel}

\section{A. General}

The endorsement of the effects doctrine by the CJEU was a major development in the regulation of foreign conduct that affected competitiveness of the EU internal market. As illustrated in InnoLux and Intel, the legal assistance provided by the single economic unit and the implementation doctrines for the regulation of such conduct was limited, taking into account of increasing globalization in which effects of a unilateral conduct transcended national boundaries. The effects doctrine has provided greater flexibility in reaching out such conduct and the CJEU has finally acknowledged it as a legal basis of exercising jurisdictional authority. Intel also connoted an increasing convergence between the US and the EU approaches to the regulation of foreign conduct under competition law. Both

81 Case C-413/14 P Intel Corporation v Commission [2016] ECLI:EU:C:2017:632, para. 46.

82 Ibid., para. 147.

83 Ibid., para. 51.

84 An opportunity for a further elaboration on the Court's comprehension of the qualified effects doctrine arose in Case C - 589/18 P Fukukawa Electric Co. v. Commission [2020] ECLI:EU:C:2019:1134. The CJEU refused to provide this further insight and decided on the appeal without getting into the merits of jurisdiction claims. 
the FTAIA's effects doctrine and the CJEU's qualified effects tests incorporated foreseeability, substantiality and immediacy (directness) as elements, necessary to be satisfied for the extraterritorial application of relevant competition rules.

International opposition towards US case law on extraterritoriality has demonstrated that the effects doctrine should be approached with caution. Regulating conduct with limited territorial nexus, the doctrine has given rise to concerns on encroachment of sovereign rights enjoyed by other States. The line that has differentiated between legitimate interests of protecting national competition and unjustifiable encroachment of sovereign rights enjoyed by other States has been proved to be a thin one. Trying to be on the right side of this line, US courts included international comity and balancing tests into their legal analysis as safety valves for alleviating concerns raised by other sovereigns. The CJEU, on the other hand, was more reluctant in addressing such concerns. Except for Gencor in which the GC evaluated the contested concentration on the basis of the "principle of non-interference' 85 , the EU equivalent of the US Supreme Court's true conflict test in Hartford Fire, the EU judicial authorities have not employed a comity or balancing test for addressing sovereignty concerns.

\section{B. Territoriality v. Extraterritoriality}

The CJEU's consistent reliance on the single economic unit and the implementation doctrines in its jurisdictional analysis provides an insight into the rationale underlying its reluctance of incorporating balancing tests into its legal analysis. The CJEU has never addressed foreign conduct without establishing their territorial nexus with the EU internal market. Despite their limited scope, the main advantages of single economic unit and the implementation doctrine stemmed from their function of providing physical nexus between foreign practices and territories of EU Member States. Once this nexus was established, the CJEU would find that the Commission's jurisdiction over these practices would be in compliance with the principles of public international $\operatorname{law}^{86}$. As there was no extraterritorial

85 Gencor/Lonrho (Case No IV/M.619) Commission Decision of 24 April 1996 OJ L11/30, paras 102-107 [1997].

86 See: Case 48/69, ICI v. Commission (Dyestuffs) [1972] ECR 619, 627; Case 89/85, A. Ahlström Osakeyhtiö and others v Commission [1988] ECR I-5193, 5243. See also; 
application of EU competition law under single economic unit and the implementation doctrines, there could be no question of whether the exercise of legislative jurisdiction would be reasonable.

The implementation doctrine as adopted in Wood pulp was very similar to the regulation of imports under the Sherman Act and the FTAIA. The FTAIA addressed instances when the Sherman Act would be applied extraterritorially and specifically carved out imports from its scope, leaving their regulation directly to the scope of the Sherman $\mathrm{Act}^{87}$. Accordingly, the application of the Sherman Act to imports would be considered under territorial rather than extraterritorial jurisdiction. This articulation was identical to the CJEU's reasoning in Wood pulp, in which the court considered the existence of sales in to the EU as sufficient for legislative jurisdiction. In this regard, the CJEU's assessment of the implementation doctrine under the auspices of territoriality principle would be construed in conformity with US case law.

In InnoLux, the Commission's omission of foreign sales between independent undertakings from the calculation of the fines imposed upon the perpetrators indicated a requirement of a territorial nexus in assessing the extent of damages subject to EU jurisdiction. Accordingly, not all damages arising due to foreign conduct could be included in the determination of fines. Only those that were incurred as a result of direct sale into the EU or an indirect sale through a vertically integrated company were taken into account in the calculation of fines imposed. It can be proposed that this indicated the adoption of a taxonomy, at least in a practical manner. Nevertheless, this proposition was negated by the reasoning of Intel, in which the GC and the CJEU refrained from distinguishing damages resulting from the contested unilateral conduct and considered them together ${ }^{88}$.

Furthermore AG Wathelet's referral to Motorola Mobility LLC v. AU Optronics Corp. in his analysis on 'direct effects' indicated that certain aspects of extraterritoriality in US law have been misunderstood by European lawyers. In Motorola Mobility LLC v. AU Optronics Corp., the Seventh Circuit's refusal of pass-on damages did not rely on a finding that

Joseph. P. Griffin, 'Extraterritoriality in U.S. and EU Antitrust Enforcement'. 67/1 Antitrust Law Journal 159, 175-76, (1999).

8715 U.S. Code $\S 6$ a.

88 Intel (Case COMP/37.990) [2010] OJ C227/13, para. 1789. 
the effects inflicted by indirect sales would be established to be indirect within the meaning of the FTAIA. The rationale underlying the Court's refusal was the Supreme Court's 'indirect purchaser doctrine' which barred the grant of remedies based on pass-on claims irrespective of their effects on domestic markets ${ }^{89}$. The Seventh Circuit did not provide any conclusion, indicating that effects created by component cartels on prices of final products, were indirect. The indirect nature of a relationship between a buyer of a composed product, and a producer of a component product would not connote effects cartelized components had on final composed products being indirect.

What was missing in the CJEU's case law was a taxonomy of conduct, which would distinguish practices with direct effects from those with indirect ones and thus territorial practices from extraterritorial ones. The indirectness of effects was determined on the basis of the availability of an intermediary price, an index that tied the values of relevant prices. If a conduct affected the prices of a certain product or service, only through an index, that is, a conduct affected the value of a reference price, from which effected prices derived their value, this effect was considered as indirect, and thus outside the scope of the effects doctrine ${ }^{90}$. For example, in the case of LCD panels, the effects of cartelized panels on the prices of other LCD panels, or final products that incorporate LCD panels, other than those cartelized are considered indirect, as these effects materialize, since prices of cartelized LCD panels operate as a reference for prices of other panels. If, on the other hand, a conduct affected prices of certain products without the intervention of an intermediary price, then these effects were considered direct, within the meaning of the effects doctrine ${ }^{91}$. For example, effects, inflicted by cartelized LCD panels upon prices of final products, incorporating cartelized panels, are direct, since these final products derive all or part of their value, directly from price-fixed panels. The fact that prices

89 Illinois Brick Co. v. Illinois, 431 U.S. 720 (1977).

90 Indirect effects could be reached over extraterritorial application of financial regulation which is not within the objectives of this paper. For the EU context, see: Joanne Scott, 'Extraterritoriality and Territorial Extension in EU law' American Journal of Comparative Law 62/1 (2014): 87.

91 For further illustrative examples see: U.S. Department of Justice \& Federal Trade Commission, Antitrust Guidelines for International Enforcement and Cooperation, 21-26 (2017). 
of final products may change in every transaction along their supply chain, cannot render indirect, the effects of cartelized panels on these prices.

In InnoLux and Intel, the territorial links, the CJEU would rely on in determining the jurisdiction in these cases, were weak. In the former, territorial link was established through a legal analysis that harmonized the single economic unit and the implementation doctrines on the basis of a preliminary finding of vertical integration. This could not be the case in the latter. Intel, a US company, produced its CPUs in the US and sold them to Lenovo, a Chinese company, which received those CPUs and incorporated them into commercial and home desktop and notebook computers in China. AMD, which was being hindered from sale of its CPUs to Lenovo and others was also a US company producing its CPUs in the US. There was no territorial link found between the EU and either the production of CPUs or their sale to Lenovo. No vertical integration or any other structural connection was present between Intel and Lenovo. The products Lenovo sold (or did not sale) into the EU internal market were computers, rather than CPUs. These facts in Intel clearly demonstrated that the practices at issue in this case were of extraterritorial nature, rather than a territorial one.

In Intel, the CJEU attempted to establish an analogy with its reasoning in Wood Pulp and argued that the qualified effects test and the implementation doctrine pursued the same objective, 'preventing conduct which, while not adopted within the EU [had] anticompetitive effects liable to have an impact on the EU market' ${ }^{92}$. Far from establishing an analogy, this argument, in fact, contradicted the Court's findings in Wood Pulp and was not in conformity with its case law. As noted above, the Court, Wood Pulp revealed that the determinative factor in establishing the adoption of a conduct was where it was implemented rather than that it was formed ${ }^{93}$. The objective of the implementation doctrine was preventing anticompetitive conducts adopted within the EU through implementation. The Court's analogy in Intel, on the other hand, referred the place where contested practices were formed.

It would be argued that the Court's construing of the qualified effects test as an alternative to the implementation doctrine was a reflection of its

92 Case C-413/14 P Intel Corporation v Commission [2016] ECLI:EU:C:2017:632, para. 45.

93 Case 89/85, A. Ahlström Osakeyhtiö and others v Commission [1988] ECR I-5193 5243, para. 16. 
reluctance in acknowledging extraterritoriality as a valid basis for establishing its jurisdiction. AG Wathelet in InnoLux, argued that the EU's judicial bodies sought to establish their jurisdiction based on territoriality principle, since the texts of Articles 101 and 102 TFEU lacked any extraterritorial dimension, unlike Sections 1 and 2 of the Sherman Act ${ }^{94}$. Accordingly, any interpretation that would allow the CJEU to assert extraterritorial jurisdiction should be avoided, due to the lack of a legal basis in the EU law. The analogy between the objectives of the implementation doctrine and qualified effects tests was proposed to overcome this hurdle. The contested practices in Intel were held to be implemented in the internal market and thus subjected to the jurisdiction of the GC and the CJEU under the territoriality principle. As the qualified effects test was held to be pursuing the same purpose and an alternative to the implementation doctrine, its application was also considered as territorial ${ }^{95}$.

In US case law, the distinction between territorial and extraterritorial application of the Sherman Act was clearly established by the FTAIA, according to which the effects doctrine was determined to be applicable only to extraterritorial conduct. The FTAIA provided two separate, not alternative, standards, that is, the standard set out for extraterritorial conduct could not be applied interchangeably to territorial conduct or vice versa. Accordingly a conduct could be subject to the effects test, only if it satisfied the elements of extraterritoriality set out under the FTAIA. International comity and the balancing tests were part of the legal analysis, when a conduct was determined to be extraterritorial and thus within the scope of the FTAIA. In that regard, AG Wahl's position in Intel, providing that such a differentiation between territorial and extraterritorial application of EU competition rules was not determinative ${ }^{96}$ was problematic as to the formulation of the legal analysis to be evaluated by the GC and the CJEU.

\section{Comity As a Necessity}

As long as the effects doctrine was considered within the ambit of the territoriality principle, international comity would never be a part of a

94 Opinion of Mr. Advocate General Wathelet in Case 231/14, InnoLux v Commission [2015] ECLI:EU:C:2015:292, paras 37-38.

95 Case C-413/14 P Intel Corporation v Commission [2016] ECLI:EU:C:2017:632, para. 18.

96 Opinion of Advocate General Wahl in Case C-413/14 Intel v Commission [2016] ECLI:EU:C:2016:788, para. 297. 
jurisdictional analysis. In US case law, international comity's role in limiting the scope of the extraterritorial application of the Sherman Act was substantial. Taking international comity into account, US courts determined that by whom actions for private compensation could be brought before judicial authorities, as well as which damages could be subject to these private claims. In Empagran, the Supreme Court pointed out that not all damages could be reclaimed by private parties, even though anticompetitive conduct causing these damages, had foreseeable, direct and substantial effects on US trade and/or commerce. Under international comity, only those who established that damages they incurred due to foreign conduct had a strong nexus with anticompetitive effects that materialized in US markets could bring private claims before US courts ${ }^{97}$.

The endorsement and the implementation of international comity did not prevent the US jurisprudence from being perceived as an illustration of legal imperialism by other states ${ }^{98}$. The legal analysis in Intel, on the other hand, indicated that any conduct, which was deemed to be liable of an impact on the internal market, would be in scope of Article 101 and 102 TFEU without a further analysis on jurisdictional rule of reason. The CJEU in Intel did not ask, for example whether a remedy or a pendency of a litigation abroad was available. Neither did it evaluate relative importance of the alleged violation in the EU compared to that in China or the US ${ }^{99}$. The Court did not even include an analysis of non-interference which would bar it from exercising its jurisdiction in the case that the contested conduct. This approach can be described as a form of legal imperialism, more aggressive than that, for which US courts have been condemned.

97 F. Hoffmann-La Roche Ltd. v Empagran, 542 U.S. 155, 167 (2004).

98 Donald. E. Knebel, 'Extraterritorial Application of US Antitrust Laws: Principles and Responses', Jindal Global Law Review 8/2, (2017): 192. See further: V. R. Grundman, 'The Imperialism: The Extraterritorial Application of United States Law', International Lawyer 14 (1980): 257; M. Sornarajah, 'The Extraterritorial Application of US Antitrust Laws: Conflict and Compromise', International and Comparative Law Quarterly 31/1 (1982): 127.

99 Criteria as to the evaluation of international comity can be found in US case law and some scholarly works. See, for example: Timberlane Lumber Co. v. Bank of America, 549 F.2d 597 (9th Cir. 1976); Mannington Mills, Inc. v. Congloeum Corp., 595 F.2d 1287 (3rd Cir. 1979); Restatement (Third) of Foreign Relations Law of the United States $\S \S 401,403$ (1987). For a further reading on comity in competition policies see: Andrew. T. Guzman (ed.), Cooperation, Comity and Competition Policy. OUP, 2011. 
International comity and balancing tests are important elements for the evaluation of extraterritorial practices under competition rules. Given the increasingly globalized international trade, it is not an exception that a conduct has (either concerted or unilateral) foreseeable, immediate (direct) and substantial cross-border effects. In this respect, satisfying the elements of the FTAIA's effects and the CJEU's qualified effects criteria is not a difficult task for both administrative and judicial authorities. Every concerted practice between multinational companies and/or unilateral conducts by globally dominant undertakings would be subject to competition proceedings under EU law, if no additional criteria, other than the effects doctrine, is adopted. The legal and political implications of such an approach have been addressed in several Advocate-General opinions in which it was alleged that the Commission's application of EU competition law to foreign conduct without any regard to international comity would amount to an encroachment of sovereign rights enjoyed by other states ${ }^{100}$.

\section{Iiyama and Leviathan Unleashed}

Intel has also provided serious legal implications as to the implementation of qualified effects doctrine in cases of private enforcement of EU competition law at national level, the repercussions of which have materialized in Iiyama ${ }^{101}$, in which follow-on damages claims were brought before UK courts ${ }^{102}$, on the basis of the Commission's previous decisions on worldwide cartels in the production and supply of cathode ray tubes (CRTs)

100، (T)he courts or administrative authorities of a State-and, mutatis mutandis, of the Community - are certainly not justified under international law in taking coercive measures or indeed any measure of inquiry, investigation or supervision outside their territorial jurisdiction where execution would inevitably infringe the internal sovereignty of the State on the territory of which they claimed to act'. Opinion of Mr AdvocateGeneral Mayras in Case 48/69, ICI v Commission (Dyestuffs) EU:C:1972:32, 695. For other AG opinions supporting an international comity standard see: Opinion of $\mathrm{Mr}$. Advocate General Wathelet in Case 231/14, InnoLux $v$ Commission [2015] ECLI:EU:C:2015:292, paras 40-42; Opinion of Mr. Advocate General Wahl in Case C413/14 Intel v Commission [2016] ECLI:EU:C:2016:788, para. 300.

${ }^{101}$ Luca Prete, 'On Implementation and Effects: The Recent Case-law on the Territorial (or Extraterritorial) Application of EU Competition Rules'. 9/8 Journal of European Competition Law \& Practice 487, 494 (2018).

102 Iiyama (UK) Ltd and others v. Samsung Electronics Co Ltd and others [2018] EWCA Civ 220; [2018] 4 C.M.L.R. 23. See also 
and LCDs ${ }^{103}$. The claimants, which were a Japanese producer and distributer of televisions and computer monitors and its subsidiaries in the EU, claimed damages incurred due to a foreign cartel of CRT and LCD producers. Judges in English High Court (HC) issued conflicting rulings on CRTs ${ }^{104}$ and $\mathrm{LCDs}^{105}$ as to the applicability of EU competition rules to foreign cartels, though the facts in each cases were substantially similar ${ }^{106}$. This inconsistency was resolved by the Court of Appeal (CoA) on the basis of very limited guidance provided by the ruling of Intel. Adhering strictly to the CJEU's conclusions, the CoA ruled that EU competition law was applicable to foreign cartels between defendants, on the basis of both the implementation doctrine and the qualified effects test, even though the cartel agreements and the first sale of cartelized CRTs and LCDs took place outside the $\mathrm{EU}^{107}$.

The major claimant in Iiyama was the Japanese parent company, which bought televisions and computer monitors incorporating cartelized CRTs and LCDs from OEMs and distributed them in the EU through its subsidiaries. The majority of damages, incurred as a result of cartel agreements, were accrued outside the EU. Referring to the Supreme Court's ruling in Empagran, the defendants argued that UK courts should refrain from exercising their jurisdiction on the basis of EU competition law, since the losses, incurred by the defendants, had not originated from anticompetitive

103 LCD_Liquid Crystal Displays (Case COMP/39.309) Commission Decision of 8 December 2010, and TV and Computer Monitor Tubes (Case COMP/39.437) Commission Decision of 5 December 2012. LCD saga of the Commission's proceedings later gave way for the defendants 'move for the dismissal of the decision in InnoLux; Case 231/14, InnoLux v Commission [2015] ECLI:EU:C:2015:451. See also: Omar Shah et al. 'Intel, iiyama, Power Cables: A Revolution in the Treatment of Territoriality and Jurisdiction in EU Competition Law?'. 10/2 Journal of European Competition Law \& Practice 80, 83 (2019).

${ }^{104}$ Iiyama Benelux BV \& others v. Schott $A G$ \& others [2016] EWHC 1207 (Ch).

${ }^{105}$ Iiyama (UK) Limited and others v. Samsung Electronics Co Ltd and others [2016] EWHC 1980 (Ch); [2016] 5 C.M.L.R. 16.

${ }^{106}$ While the CRT claims were dismissed on the ground that indirect sales to the EU would not be regarded as implementation, LCD claims were confirmed under the implementation doctrine, due to the final arrival of these products to the EU. For an analogous friction in US case law, see Seventh and Ninth Circuits 'respective decisions: Motorola Mobility LLC v. AU Optronics Corp. 775 D.3d 816 (7th Cir. 2015) and; United States v. Hui Hsiung 778 F.3d 738 (9th Cir. 2015).

${ }^{107}$ Iiyama (UK) Ltd and others v. Samsung Electronics Co Ltd and others [2018] EWCA Civ 220; [2018] 4 C.M.L.R. 23, paras 88-89. 
effects, the contested practices created in the $\mathrm{EU}^{108}$. The CoA rejected this argument on the ground that competition laws of the US and the EU were substantially different ${ }^{109}$. The main difference that the Court referred to as an illustration was the availability of treble damages in US law ${ }^{110}$, which would provide incentives for victims of worldwide cartels to seek remedies before US courts ${ }^{111}$. This was not the case in the $\mathrm{EU}^{112}$. According to the Court, EU law did not offer a 'persuasive force' for foreign victims to bring their claims before EU courts ${ }^{113}$.

The CoA also noted that even though comity concerns on the private enforcement of EU competition law were also addressed in various Advocate General opinions, the GC and the CJEU consistently ignored them in their conclusions ${ }^{114}$, construing that the nexus between damages incurred by claimants and anticompetitive effects on EU markets was left deliberately outside the territoriality analysis by the EU courts. Damages arising from domestic and/or foreign effects of an anticompetitive conduct would be evaluated in the determination of fines to be imposed by the Commission. Nevertheless, whether damages sought by the claimants originated from domestic or foreign anticompetitive effects was not a part of the Court's jurisdictional analysis ${ }^{115}$.

The CoA's finding of damages as a factor in assessing fines to be imposed should not indicate that the extraterritoriality of these damages

${ }^{108}$ Ibid., paras 53-54

${ }^{109}$ Ibid., para. 105

110 Section 4 of the Clayton Act provides that "any person who shall be injured in his business or property by reason of anything forbidden in the antitrust law (...) shall recover threefold the damages by him sustained, and the cost of suit, including a reasonable attorney's fee". 15 U.S. Code $\S 15$. See also William E. Kovacic, 'Extraterritoriality, Institutions, and Convergence in International Competition Policy', 97 Proceedings of the Annual Meeting (ASIL), 309, 311 (2003).

${ }^{111}$ Iiyama (UK) Ltd and others v. Samsung Electronics Co Ltd and others [2018] EWCA Civ 220; [2018] 4 C.M.L.R. 23, para 105.

112 According to the recital 44 of 2014 Damages Directive, national courts should refrain from issuing charges more than those paid for the compensation of actual losses. Directive 2014/104/EU of the European Parliament and of the Council of 26 November 2014 on certain rules governing actions for damages under national law for infringements of the competition law provisions of the Member States and of the European Union [2014] OJ L $349 / 1$.

${ }^{113}$ Iiyama (UK) Ltd and others v. Samsung Electronics Co Ltd and others [2018] EWCA Civ 220; [2018] 4 C.M.L.R. 23, para. 106

114 Ibid.

115 Ibid. paras 116-117 
would result in a direct omission of these damages from the total amount, claimants seek for compensation. 2014 Damages Directive does not include any provision limiting the compensation of losses incurred due to anticompetitive effects occurring in the EU. Article 3.1 of the Directive incorporates a 'right to full compensation' providing that ' theMember States shall ensure that any natural or legal person who has suffered harm caused by an infringement of competition law is able to claim and to obtain full compensation for that harm'. The right to full compensation involves 'the right to compensation for actual loss and for loss of profit, plus the payment of interest'. Victims of anticompetitive conducts are entitled to bring claims of full compensation before national courts. Whether a portion or all of their losses are incurred outside the EU is irrelevant for the assessment of fines to be imposed by national authorities. In that regard, the CoA's position on the extraterritoriality of damages incurred does not connote a limitation to the scope of EU competition law with respect to foreign practices.

Iiyama illustrated the legal implications of the qualified effects doctrine, when it was applied at national level against a foreign conduct without any forms of jurisdictional rule of reason, such as international comity and balancing tests. As noted, the qualified effects doctrine incorporated a test which was not difficult to satisfy. Lacking an additional criterion adhering to rights enjoyed by other sovereign states would result in every conduct having anticompetitive effects on the internal market being subject to EU competition law at both the Union and national level.

\section{Conclusion}

This paper questioned the CJEU's designation of qualified effects doctrine as a means to establish territorial jurisdiction over extraterritorial conduct. In US law, the effects doctrine was established as a legal basis for US Courts to exert their jurisdiction under the extraterritoriality. In EU law, on the other hand, the legal basis on which the CJEU based its decision in Intel, continued to be territorial jurisdiction. The consequences of this divergence were immense. Given the introduction of new supply chains ${ }^{116}$ in

${ }^{116}$ See: Dick K. Nanto, 'Globalized Supply Chains and U.S. Policy 'in America in the 21st Century: Political and Economic Issues Series: Globalized Supply Chains and Policy, ed. Solomon Mensah (2010). For the implications of new business models to the application of competition rules see also: Leon B. Greenfield, et al., 'Foreign Component Cartels and the U.S. Antitrust Laws: A First Principle Approach 'Antitrust 29/2 (2015):18; Ellen 
an increasingly globalized world, in which the effects of a particular conduct produce cross-border victims, the integration of multiple markets by multinational companies results in a situation, in which any conduct taken by a legal entity in one market has cross-border effects in other markets. The extraterritorial implications of commercial activities happens to be frequent rather than exceptional.

The effects doctrine has proved to be a valuable instrument in determining foreign conducts with domestic effects. Nevertheless, due to the growing integration of world markets, the extent of market practices that would meet the elements of this doctrine has been broadening, rendering the doctrine's functioning of jurisdictional delimitation redundant. As Iiyama clearly illustrated, without the introduction of a new criteria, most of anticompetitive practices perpetrated abroad would fall within the scope of national jurisdictions in the EU.

The extraterritorial application of domestic rules was regarded as an exception to a general rule that national law should be applied territorially. In this regard, US courts subjected the extraterritoriality of the Sherman Act to a strict interpretation, in a manner that the extent of foreign conduct that could be reached out by the Sherman Act was limited. This would never be the case for EU law, unless the CJEU acknowledged that its application of EU competition law to foreign conduct through the qualified effects test constituted an extraterritorial application of its jurisdiction. In order to evade from an overarching extension of EU jurisdiction over foreign conduct, the CJEU must reconceptualize its qualified effects doctrine within the premises of extraterritoriality. Only then, can international comity and jurisdictional rule of reason be incorporated into the legal analysis on qualified effects foreign conduct would have on the internal market.

Meriwether, Motorola Mobility and the FTAIA: If Not Here, Then Where? Antitrust 29/2 (2015): 8; Kenneth W. Dam, 'Extraterritoriality in an Age of Globalization: The Hartford Fire Case 'The Supreme Court Review (1993): 289; Jae Hyung Ryu, 'Deterring Foreign Component Cartels in the Age of Globalized Supply Chains 'Wake Forest Journal of Business and Intellectual Property Law 17/1 (2016): 81; Megan L. Masingill, 'Extraterritoriality of Antitrust Law: Applying the Supreme Court's Analysis in RJR Nabisco to Foreign Component Cartels 'American University Law Review 68/2 (2019): 621. 


\section{Bibliography}

\section{Primary Sources (Asli Kaynaklar)}

Council Regulation on the concentrations between undertakings 4064/89 [1989] OJ L395/1 (replaced by Reg. 139/2004 [2004] L24/1).

Council Regulation on the concentrations between undertakings 4064/89 [1989] OJ L395/1 (replaced by Reg. 139/2004 [2004] L24/1).

Directive 2014/104/EU of the European Parliament and of the Council of 26 November 2014 on certain rules governing actions for damages under national law for infringements of the competition law provisions of the Member States and of the European Union.

Guidelines on the method of setting fines imposed pursuant to Article 23(2)(a) of Regulation No 1/2003, 2006/C 210/02.

\section{Secondary Sources (Tali Kaynaklar)}

Akbar, Yusuf. 'The Extraterritorial Dimension of US and EU Competition Law: A Threat to the Multilateral System', Australian Journal of International Affairs 53/1, (1999): 113-125.

Alford, Roger P. 'Extraterritorial Application of Antitrust Laws: The United States and European Community Approaches' Virginia Journal of International Law 33/1, (1992): 259-87.

Amato, Guiliano. Antitrust and the Bounds of Power: the Dilemma of Liberal Democracy in the History of the Market. Oxford: Hart Publ., 1997.

Dam, Kenneth W. 'Extraterritoriality in an Age of Globalization: The Hartford Fire Case 'The Supreme Court Review (1993): 289-328.

Damro, Chad.'Building an International Identity: The EU and Extraterritorial Competition Policy', Journal of European Public Policy 8/2 (2001): 208-226.

Damrosch, Lori F. Et al., International Law: Cases and Materials. 5th Ed. West, 2009.

Fox, Elanor. M. 'National Law Global Markets and Hartford: Eyes Wide Shut' Antitrust Law Journal 68/1 (2000): 73-86.

Fox, Elanor. M. 'Extraterritorial Jurisdiction, Antitrust and the EU Intel Case: Implementation, Qualified Effects, and the Third Kind', Fordham International Law Journal 42/3, (2019): 981-98. 
Greenfield, Leon B. et al. 'Foreign Component Cartels and the U.S. Antitrust Laws: A First Principle Approach 'Antitrust 29/2 (2015):18-27.

Griffin, Joseph P. 'Extraterritoriality in the US and EU Antitrust Enforcement', Antitrust Law Journal 67/1 (1999): 159-199.

Grundman, V. Rock 'The Imperialism: The Extraterritorial Application of United States Law', International Lawyer 14 (1980): 257-66.

Jones, Alison \& Sufrin, Breanda. EU Competition Law: Text, Cases, and Materials. 7. Bask1. Oxford, 2019.

Knebel, Donald E. 'Extraterritorial Application of US Antitrust Laws: Principles and Responses' Jindal Global Law Review 8/2 (2017): 181-202.

Kovacic, William E. 'Extraterritoriality, Institutions, and Convergence in International Competition policy', Proceedings of the Annual Meeting (ASIL) 97/1 (2003): 309-312.

Masingill, Megan L. 'Extraterritoriality of Antitrust Law: Applying the Supreme Court's Analysis in RJR Nabisco to Foreign Component Cartels 'American University Law Review 68/2 (2019): 621-665.

Meriwether, Ellen. 'Motorola Mobility and the FTAIA: If Not Here, Then Where?' Antitrust 29/2 (2015): 8-17.

Nanto, Dick K. 'Globalized Supply Chains and U.S. Policy 'in America in the 21st Century: Political and Economic Issues Series: Globalized Supply Chains and Policy, ed. Solomon Mensah (2010).

Prete, Luca. 'On Implementation and Effect: The Recent Case-law on the Territorial (or Extraterritorial?) Application of EU Competition Rules', Journal of European Competition Law \& Practice 9/8 (2018): 497-495.

Ryu, Jae Hyung. 'Deterring Foreign Component Cartels in the Age of Globalized Supply Chains 'Wake Forest Journal of Business and Intellectual Property Law 17/1 (2016): 81-112.

Scott, Joanne .'Extraterritoriality and Territorial Extension in EU law' American Journal of Comparative Law 62/1 (2014): 87-126.

Sornarajah, Muthucumaraswamy." The Extraterritorial Application of US Antitrust Laws: ConfliCt and Compromise', International and Comparative Law Quarterly 31/1 (1982): 127-49.

Trenor, Josh A. 'Jurisdiction and the Extraterritorial Application of Antitrust Law after Hartford Fire' The University of Chicago Law Review 62, (1995): 15831618 . 


\section{Case Law (İçtihatlar)}

S.S. 'Lotus' (France v. Turkey), 1927 P.C.I.J. (ser. A) No. 10.

United States v. Aluminum Co of America, 148 F.2d 416424 (2d Cir. 1945).

United States v. Imperial Chemicals Industries Ltd. 100 F. Supp. 504 (S.D.N.Y. 1951).

United States v. Watchmakers of Switzerland Info. Center, Inc. 168 F. Supp. 904 (S.D.N.Y. 1958).

Grosfillex \& Fillistorf, 64/233/EEC [1964] OJ L 64/915.

Sabre Shipping Corp. v. American President Lines Ltd. 285 F. Supp. 949 (S.D.N.Y. 1968).

In re the Cartel in Aniline Dyes [1969] OJ L195/11.

Case Concerning Barcelona Traction, Light and Power Company Ltd. (Belgium v. Spain) ICJ. 1970.

Case 48/69, ICI v. Commission (Dyestuffs) [1972] ECR 619.

Timberlane Lumber Co. v Bank of America, 549 F2d 597 ( $9^{\text {th }}$ Cir 1976).

Illinois Brick Co. v. Illinois, 431 U.S. 720 (1977).

Mannington Mills, Inc. v. Congloeum Corp., 595 F.2d 1287, 1297 (3rd Cir. 1979)

Case 170/83, Hydrotherm Gerätebau GmbH v Compact del Dott. Ing. Mario Andreoli \& C. Sas. [1985] ECR 3016.

Wood Pulp (Case IV/29725) Commission Decision 85/202/EEC [1985] OJ L85/1.

Case 89/85, A. Ahlström Osakeyhtiö and others v Commission [1988] ECR I-5193.

Case T-11/89, Shell International Chemical Company Ltd [1992] ECR II-884.

Hartford Fire Ins. Co. v. California, 509 U.S. 764 (1993).

Case 73/95 P, Viho Europe BV v Commission EU:C:1996:405.

Gencor/Lonrho (Case No IV/M.619) Commission Decision of 24 April 1996 OJ L11/30 [1997].

Case T-102/96, Gencor Ltd v. Commission [1999] ECR II-753.

F. Hoffmann-La Roche Ltd. v Empagran, 542 U.S. 155 (2004).

Case T-325/01 Daimler Chrysşer Ag v Commission [2005] ECR II-3326.

Case 97/08 Akzo Nobel NV v Commission [2009] ECR I-8237. 
Intel (Case COMP/37.990) [2010] OJ C227/13.

LCD — Liquid Crystal Displays (Case COMP/39.309) [2010] OJ 2011 C 295/8.

TV and Computer Monitor Tubes (Case COMP/39.437) Commission Decision of 5 December 2012.

T-91/11, InnoLux v Commission, [2014] ECLI:EU:T:2014:92.

T-286/09, Intel v Commisson, ECLI:EU:T:2014:547.

Case 231/14, InnoLux v Commission [2015] ECLI:EU:C:2015:451.

Cases 293-294/13 P, Fresh Del Monte Produce Inc. v. Commission [2015] ECLI:EU:C:2015:416.

Motorola Mobility LLC v. AU Optronics Corp. 775 D.3d 816 (7th Cir. 2015).

United States v. Hui Hsiung 778 F.3d 738 (9th Cir. 2015).

Case C-413/14 P Intel Corporation v Commission [2016] ECLI:EU:C:2017:632.

Iiyama Benelux BV \& others v. Schott $A G$ \& others [2016] EWHC 1207 (Ch).

Iiyama (UK) Limited and others v. Samsung Electronics Co Ltd and others [2016] EWHC 1980 (Ch); [2016] 5 C.M.L.R.

Iiyama (UK) Ltd and others v. Samsung Electronics Co Ltd and others [2018] EWCA Civ 220; [2018] 4 C.M.L.R. 